DOI https://doi.org/10.30525/978-9934-26-039-1-43

\title{
ОСОБЛИВОСТІ РЕАЛІЗАЦІЇ КАТЕГОРІЇ ІНТЕРТЕКСТУАЛЬНОСТІ В НАВЧАЛЬНОМУ ТЕКСТІ
}

\author{
Кібальнікова Т. В. \\ кандидат філологічних наук, \\ доиент кафедри англійської мови та методики ї̈ викладання \\ Центральноукраїнського державного педагогічного університету \\ імені Володимира Винниченка \\ м. Кропивницький, Україна
}

Наразі освіта стає однією з провідних складових соціокультурної політики в світі та в Україні зокрема. Відповідно, особливої значущості набуває такий напрямок як педагогічна лінгвістика. У межах дискурсології, 3'являється поняття «науково-педагогічного дискурсу» (М. Култхард і Дж. Синклер), яке потрапляє до кола уваги сучасних дослідників (І.Є. Баранова, А.Р. Габідулліна, Г.В. Сорокова, М.А. Самкова та ін.). Отже, обрана тема $є$ актуальною. Услід за М.А. Самковою розуміємо навчально-педагогічний дискурс як «систему організованого навчання / спілкування, яка полягає у взаємодії педагога та учнів шляхом навчальних текстів та інших знакових комплексів у межах цілісної навчально-педагогічної ситуації» [7, с. 104].

Оскільки навчальний текст $\epsilon$ важливою складовою навчальнопедагогічного дискурсу, метою цієї наукової розвідки є уточнити поняття навчального тексту, а також розглянути особливості реалізації категорії інтертекстуальності в процесі його створення.

Ще й досі не існує універсального визначення поняття навчального тексту. Так, Х.А. Захра вважає навчальний текст мовленнєвим твором, препарованим відповідно до мовної компетенції того, хто навчається, а також відповідно до правил функціональної стилістики, лінгводидактики тощо, який передбачає існування прототипу у вигляді оригінального джерела [6, с. 118-125]. Н.Ф. Баландіна розглядає навчальний текст як «засіб формування мовної, мовленнєвої та соціокультурної компетенції учнів, наділений багатим дидактичним потенціалом» [2, с. 15]. На наш погляд, вичерпне визначення навчального тексту формулює А.Е. Бабайлова: «текст, організований 3 дидактичною метою у змістовому, мовному і композиційному плані в єдину систему; частина сукупної інформації підручника, призначеного для керованого становлення текстової діяльності, на основі якої подається система знань 
3 певної дисципліни <..>, прищеплюються вміння та навички людям певної групи на певному етапі навчання» [1, с. 130].

Однією $з$ базових текстотвірних категорій навчального тексту $\epsilon$ категорія інтертектуальності. Л.Г. Тюріна вважає, що «інтертекстуальна адресність» навчального тексту оцінює композиційно-змістову та семантико-прагматичну співвіднененість тексту з іншими текстами $[8$, c. 7$]$.

Навчально-методичні комплекси для вивчення іноземної мови здебільшого складаються 3 підручника, робочого зошита 3 друкованою основою і книги для вчителя. До того ж, учитель користується й невербальними матеріалами: аудіо-та відеоматеріалами, флешкартками, тощо. Послуговуючись термінологією Н.В. Данилевської, можемо назвати навчально-методичний комплекс «надтекстом», адже він уміщує «сукупність висловлювань або текстів, об'єднаних змістовно і ситуативно» [5]. У цьому аспекті слушною є думка А.Р. Габідулліної, котра виокремлює вертикальну (зовнішню) вісь інтертекстуальності, що реалізується за рахунок міжтекстових зв'язків навчальних текстів у межах надтексту, та горизонтальну (внутрішню) інтертекстуальність, яка актуалізується в межах одного навчального тексту [4].

Основними вербальними засобами актуалізації інтертекстуальності в навчальних текстах підручника $\epsilon$ використання цитат, алюзій, ремінісценцій. Цитата $\epsilon$ найбільш експліцитно вираженим видом міжтекстових зв'язків і в широкому розумінні може охоплювати алюзію й ремінісценцію. Одним із видів цитування в широкому розумінні цього терміну є тексти різної жанрово-стильової приналежності, вбудовані в структуру підручника.

Продуктивним засобом актуалізації міжтекстових зв'язків у підручнику $\epsilon$ текстовий парафраз. На думку А.Р. Габідулліної, парафрастичність, або «здатність навчальних текстів функціонувати у множинності варіантів» [3, с. 76], є властивістю навчально-педагогічного дискурсу в цілому. У навчальному тексті підручника той самий навчальний матеріал багаторазово повторюється як у межах одного параграфа, так і в межах усього підручника в різних жанрових формах. Наприклад, граматичний матеріал часто подається спочатку в контексті, в ролі якого може бути уривок тексту будь-якого жанру, де граматичні структури, які підлягають вивченню, виділені графічно, потім надається пояснення граматичного явища, що вивчається, і правило. Таким чином, відбувається зв'язок первинного тексту і вторинного (пояснення, правила, тощо). 
Окрім включення вторинного тексту в оригінальному або трансформованому вигляді до структури підручника, існує ще семіотичний / невербальний вид міжтекстового зв'язку, або інфографіка. У дидактичному плані інфографічні елементи - це таблиці, схеми, діаграми, тощо, які використовуються з навчальною метою.

Отже, категорія інтертекстуальності є однією з основних текстотвірних категорій навчального тексту, яка сприяє формуванню міжпредметних зв'язків та забезпечує реалізацію принципу послідовності в навчанні. У підручнику з іноземної мови інтертекстуальні зв'язки покликані розвивати мовну, мовленнєву, а також соціокультурну компетентності, які $є$ складовими іншомовної комунікативної компетентності.

\section{Література:}

1. Бабайлова А.Э. Текст как продукт, средство и объект коммуникации при обучении неродному языку: Социопсихолингвистические аспекты. Саратов, 1987. 152 с.

2. Баландіна Н.Ф. Навчальний текст як засіб породження нових смислів. Науковий часопис НПУ імені М. П. Драгоманова. 2017. Вип. 58. С. 14-19.

3. Габідулліна А.Р. Навчально-педагогічний дискурс як лінгвістичний феномен. Мовознавство. 2009. № 6. С. 70-78.

4. Габидуллина А.Р. Учебно-педагогический дискурс: монография. Горловка: Изд-во ГТПИИЯ. 2009. 292 с.

5. Данилевская Н.В. Сверхтекст. Стилистический энциклопедический словарь русского языка. URL: https://stylistics.academic.ru/150/\% D0\%A1\%D0\%B2\%D0\%B5\%D1\%80\%D1\%85\%D1\%82\%D0\%B5\%D0\%B $\mathrm{A} \% \mathrm{D} 1 \% 81 \% \mathrm{D} 1 \% 82$ (дата звернення 20.02.21).

6. Захра Х.А. Учебный текст как неотъемлемая часть лингводидактической системы. Вестник Российского университета дружбы народов. 2012. № 3. С. 118-125

7. Самкова М.А. Интертекстуальность и интердискурсивность как категории учебно-педагогического дискурса. Bonpocbl когнитивной лингвистики. 2013. № 4(037). С. 104-108.

8. Тюрина Л.Г. Теоретико-методологическое обоснование модели учебной книги для профессионального образования: автореф.дис. ... д-ра филол.наук: спец. 05.25.03 «Библиотековедение, библиографоведение и книговедение»; Московский гос. университет печати. Москва, 2007. 46 с. 